
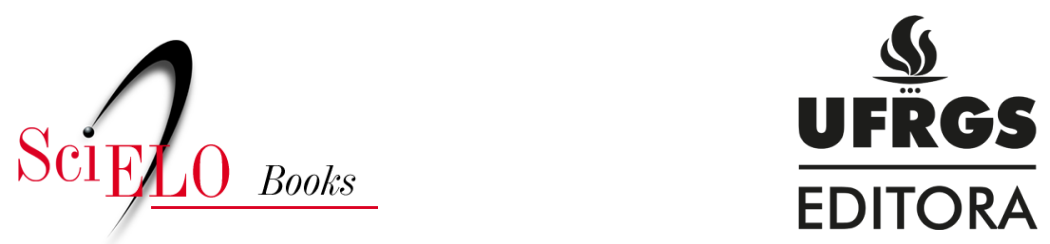

Parte II - Experiências de Aprendizagem

\title{
Capítulo 6 - Mães, donos e outros bichos nas narrativas das crianças
}

\author{
Chantal Medaets
}

\section{SciELO Books / SciELO Livros / SciELO Libros}

MEDAETS, C. Mães, donos e outros bichos nas narrativas das crianças. In: "Tu garante?": aprendizagem às margens do Tapajós [online]. Porto Alegre: Editora da UFRGS, 2020, pp. 191-221. Entremeios series. ISBN: 978-65-5725-026-6. https://doi.org/10.7476/9786557250402.0008.

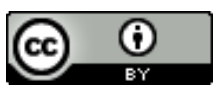

All the contents of this work, except where otherwise noted, is licensed under a $\underline{\text { Creative }}$ Commons Attribution 4.0 International license.

Todo o conteúdo deste trabalho, exceto quando houver ressalva, é publicado sob a licença Creative Commons Atribição 4.0.

Todo el contenido de esta obra, excepto donde se indique lo contrario, está bajo licencia de la licencia Creative Commons Reconocimento 4.0. 


\section{Capítulo 6 - MÃes, donos e outros bichos NAS NARRATIVAS DAS CRIANÇAS}

Quando a gente esquece os bichos, ai que eles voltam. (Ana Paula, 10 anos)

"Bora da história?" Assim começa uma brincadeira que reúne meninos e meninas, em geral entre 2 e 11 anos, durante todo o ano nas comunidades do Tapajós. Se outras brincadeiras têm época (piáo, caçar saúvas, algumas brincadeiras de mão), é difícil um dia passar sem que se veja um grupinho de cinco ou seis crianças, à sombra de uma árvore, ouvindo e contando histórias. Sempre assustadoras, as narrativas falam de bichos, encantados, visagens e engerados, ${ }^{1}$ e algumas retomam contos tradicionais que as crianças escutam ou leem na escola (como Os três porquinhos ou Branca de Neve) ou filmes (Boneco assassino, Dragon...). A capacidade de concentração das crianças durante essas sessōes de narração é grande: narradores podem cativar seus ouvintes por mais de dez minutos com uma mesma história e, quando interrompidos (geralmente por um adulto pedindo que levem ou busquem alguma coisa), são capazes de retomar o "fio da meada" exatamente onde tinham parado. Uma mesma criança, desde que sua audiência aprecie a narração, pode engatar uma história na outra, diversas vezes.

Os adultos da regiáo também são exímios contadores de histórias, e autores que estudam populaçóes ribeirinhas em diferentes pontos da Amazônia, do Acre ao estuário do Amazonas, constataram o gosto de seus interlocutores por narrativas cujos personagens principais são, em grande medida,

\footnotetext{
1 Os termos acima, assim como "mãe" e "dono", são usados no sentido localmente dado a eles e aparecerão sem aspas no texto para facilitar a leitura.
} 
os mesmos das narraçóes das crianças do Tapajós. ${ }^{2}$ Alguns pesquisadores consideram, assim, que as tramas dessas histórias revelam elementos importantes do que poderia ser pensado como uma cosmologia regional compartilhada (Galvão, 1955, p. 27; Harris, 2014, p. 113 e ss.; Lima, 2014; Slater, 1994, p. 14 e ss.; Valentin, 2001, p. 40). Não se trata, no entanto, de uma "ordem cosmológica estável” (Harris, 2014, p. 114), com classificações bem definidas e fixas de cada tipo de entidade. Muitas pessoas, habitantes das mesmas localidades, divergem entre si. Se a Curupira, por exemplo, é sistematicamente considerada como a "mãe da mata", para alguns ela é um encantado e para outros, não; já o encantado que "levou para o fundo" a família e seus animais domésticos em Parauá, para alguns é uma Cobra-Grande, para outros, um Boto, e assim por diante. As divergências e contradições fazem parte do sistema, "não há nenhum tipo de controle institucional ou disciplinante dessas classificaçôes" (Harris, 2014, p. 114). Meus interlocutores adultos falam de "espíritos da natureza" ou de "bichos" para se referir ao conjunto das criaturas que habitam a floresta (como o Jurupari, a Curupira, o Macacão, etc.) ou as profundezas de rios e igarapés (como o Boto, a Cobra-Grande, o Cavalo-Marinho encantado, etc.). As crianças usam somente o termo "bicho".

2 Sobre a centralidade dessas narrativas orais, ver, por exemplo: Faulhaber (1998), que pesquisou nos arredores de Tefé, Amazonas; Harris (2008), para uma análise histórica de narrativas no interior do estado do Pará e Harris (2014), para materiais de comunidades de várzea do rio Amazonas no município de Óbidos, Pará; Lima Ayres (1992), pesquisando no Médio Solimóes, Amazonas, e Lima (2014), quando a mesma autora propóe uma análise comparativa regional; Maués (2006), associando as narrativas de Boto à "pajelança cabocla"; Slater (1994), discutindo um grande conjunto de histórias de Boto coletadas nas cidades de Parintins e Manaus, entre seringueiros do Acre e comunidades quilombolas e rurais de diferentes comunidades da várzea do Amazonas; Stoll (2016), trazendo as narrativas do "encantamento" de um pajé-sacaca no Baixo Tapajós; Vaz e Carvalho (2013), que recolhem versóes de narrativas que circulam na região do Baixo Tapajós; Valentin (2001), que estrutura sua etnografia em torno das histórias que coletou na zona costeira do Pará. 
Neste capítulo, parto de narrativas de crianças, gravadas durante a brincadeira "da história", para explorar o imaginário que elas partilham e recriam continuamente junto com os adultos da regiáo. ${ }^{3}$ A partir dos temas que aparecem nessas narrativas, histórias contadas por adultos, bem como suas práticas e suas reflexôes sobre o assunto, serão evocadas. ${ }^{4}$ Narrativas de crianças ribeirinhas sobre "Botos, Mapinguaris e Curupiras", na cidade de Porto Velho, Rondônia, também interessaram Tania Rocha Parmigiani (2007), mas a autora analisou-as no contexto da sala de aula, quando registrou comentários e reescritas dessas histórias após uma versão delas ter sido lida para as crianças. Preocupada com a aprendizagem da escrita, a autora analisa em que medida o trabalho com essas histórias é estimulante para as crianças na escola. Mais próxima da perspectiva que adoto aqui, Pires (2011) explora as ideias das crianças de Catingueira, Paraíba, sobre mal-assombros e religiáo, usando de desenhos e redaçôes, além da observação etnográfica. Num contexto majoritariamente católico, a autora mostra como a aprendizagem de diferentes aspectos das práticas religiosas e do temor aos mal-assombros se dá de maneira diluída no cotidiano, não necessariamente em momentos-chave, como a missa ou o catecismo: "À medida que aprendem como se comportar como verdadeiros 'rapazinhos' ou 'mocinhas' [...], quando aprendem a ser filhas, irmãs, netas, amigas, vizinhas é que as crianças também aprendem sobre religião e os mal-assombros" (Pires, 2011, p. 231-232). Pierre Déléage (2009), trabalhando sobre a aquisiçáo de saberes sobre os yoshi, entidades causadoras de doenças, entre os Sharanahua (populaçáo indígena que vive às margens do rio Purus, no Peru), mostra que essa aquisição

\footnotetext{
3 Baseio-me em um conjunto de 86 histórias gravadas durante essa brincadeira, a cada vez proposta pelas próprias crianças. Elas foram recolhidas durante os trabalhos de campo do doutorado (2010-2012) e do pós-doutorado que realizei no Programa de Pós-Graduação em Educação da PUCRS (2016).

${ }^{4}$ Para isso, eu me baseio em minhas notas de campo e num conjunto de 55 histórias narradas por adultos que gravei durante os trabalhos de campo acima citados.
} 
se faz também bastante progressivamente, em interações ordinárias onde as crianças escutam relatos sobre doenças causadas por yoshi, relatos de curas dessas doenças por xamãs, e são repreendidas tendo a figura dos yoshi como punidor ("um yoshi vai vir te comer!”). Assim seriam construídas as representaçôes das "pessoas comuns" (Déléage, 2009, p. 63) sobre esses seres, enquanto uma iniciação ritual se faz necessária para ir além e tornar-se um especialista sobre os yoshi, um xamã (Déléage, 2009, p. 68-84).

No Tapajós, esse tipo de aprendizagem difusa no conjunto de interaçôes cotidianas é também fundamental para que as "pessoas comuns", enquanto crianças, construam saberes sobre os bichos e suas maneiras. No entanto, ainda na infância, há aqui um momento privilegiado para rememorar e pôr em palavras seus conhecimentos sobre esses seres: as sessôes em que se ouve e se conta histórias "de bicho", testando assim maneiras apropriadas de narrar - e pensar - suas açôes.

O capítulo se divide em duas partes. Farei inicialmente uma primeira caracterização dessas histórias, apresentando seu contexto de enunciação (quem são os narradores e os ouvintes? Quais são as situaçôes propícias a essas trocas? Quais as regras que regem a brincadeira?) e os gêneros narrativos de que podemos aproximar as narrativas de crianças e de adultos. Na segunda parte, o conteúdo das histórias será apresentado através de uma exploração das múltiplas facetas dos personagens, tal como elas aparecem nas histórias recolhidas.

\section{Caracterizaçấo geral das histórias}

NARRADORES, OUVINTES E CONTEXTOS DE ENUNCIAÇÃO

Comecemos por precisar que as histórias "de bicho" não são histórias infantis, não são histórias "para crianças". Elas são 


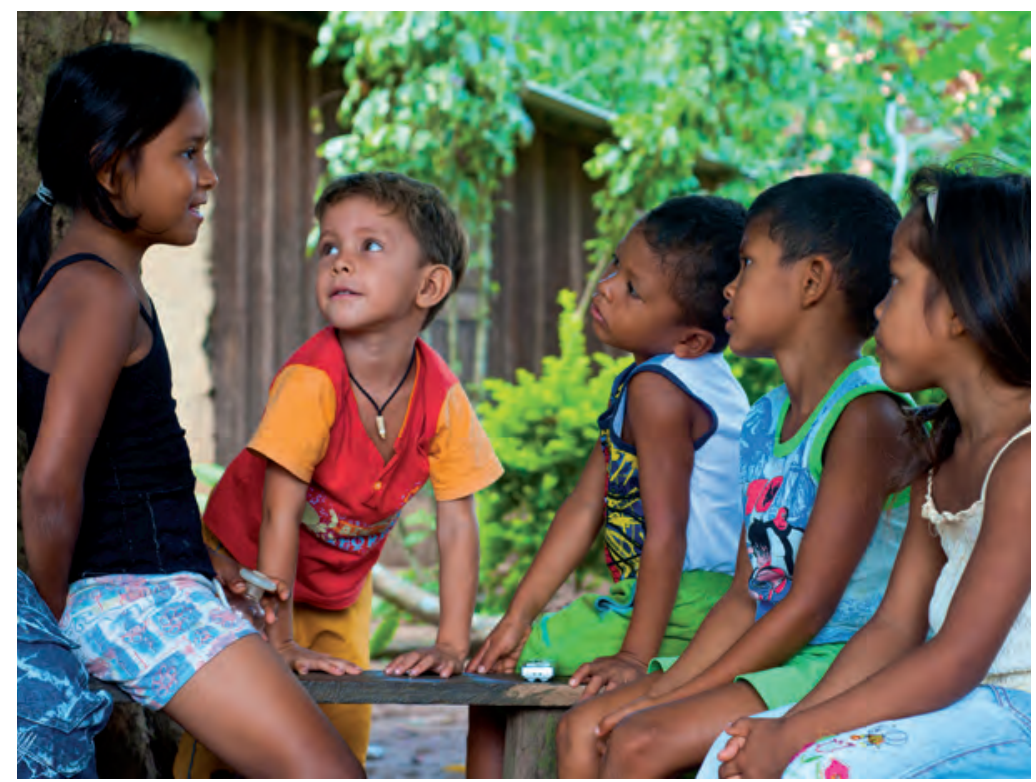

Samara contando uma história sobre o Jurupari (Pinhel, agosto de 2011). Fotografia de Lucie Robieux.

contadas entre pares: os adultos as compartilham entre si e as crianças fazem o mesmo.

Quando algum adulto começa a falar de uma caçada, de bichos ou das "malinagens" de algum encantado, não faltam crianças com olhos e ouvidos atentos por perto. Elas não costumam olhar diretamente os adultos, mas de soslaio, fazendo ao mesmo tempo alguma outra coisa (riscar com um galho a areia, mexer num cachorro), e afastam-se e reaproximam-se discretamente. Enquanto um adulto narra, as crianças também não interferem, seja para perguntar, comentar e menos ainda para iniciar elas mesmas alguma história. Se ninguém impede que elas acompanhem as narrativas, nada é feito para incluí-las: os narradores adultos não lhes dirigem o olhar e não fazem qualquer adaptação na fala (velocidade de locução, escolher ou evitar certas palavras, etc.). É difícil saber até que ponto as crianças 
entendem as nuances das histórias narradas pelos adultos, mas quando estão elas mesmas contando e outra criança questiona a versão apresentada, se defendem dizendo que a ouviram de um adulto, "foi o papai Maró que contou", "a dona Justina que viu, ela contou lá em casa”. Poucas vezes ouvi falar de uma avó cuidadosa que se dispunha a contar exclusivamente para crianças as histórias "de bicho", embora seja possível que, na intimidade dos lares, isso aconteça mais do que se diga. ${ }^{5}$ Também é preciso notar que alguns professores e professoras, sobretudo aqueles que integraram o movimento indígena, podem contar essas histórias em suas aulas. As crianças às vezes mencionam sua influência: "É assim, sim, foi assim que a professora Evelina contou”, diz Samara (10 anos), respondendo a uma crítica de Éric (9 anos) sobre sua narração.

Quando estão entre elas, as "sessóes" de histórias tomam a forma de uma brincadeira. "Bora da história?", alguém propóe, como podem propor "bora da pira?", "bora do esconde?”, etc. Se quem teve a ideia encontra parceiros, o grupo buscará um lugar para sentar à sombra. Diferentemente dos adultos, as crianças indicam claramente, muitas vezes com fórmulas padronizadas, o começo e o fim de uma história ("eram três caçadores, né?", "eu vou contar a história da...", "era uma vez...", "a velha plantou chicória, acabou a história”). Os grupos são formados por crianças de diversas idades: de pequenos de 2 anos que começam a andar de forma autônoma até crianças de 11 anos. Os mais velhos, que aspiram a ser considerados “jovens”, evitam se juntar às crianças, nessa ou em outras brincadeiras.

Mas participar da brincadeira não significa poder narrar uma história. É raro ver uma criança de 4 ou 5 anos tentar iniciar uma narração, e é a partir de 7 ou 8 anos que ela começa realmente a

\footnotetext{
5 Em todo caso, a situação contrasta com aquelas em que há um investimento sistemático na transmissão intergeracional de narrativas orais dentro da família, como observaram, por exemplo, Finnegan (1967), para os Limba no norte de Serra Leoa, e Wilson (1996), para os Dakota nos Estados Unidos.
} 
poder contar uma história inteira, do começo ao fim, sem que as outras a interrompam e a impeçam de continuar por julgarem que ela "ainda não sabe". De fato, não há na brincadeira regras ou nada que indique que as crianças esperam uma distribuição equitativa da participação. Não se ouve ninguém reclamar que alguma criança tenha "contado muitas" histórias e monopolizado a fala. Cada um pode narrar enquanto cativa a atenção de seus ouvintes, o que faz com que poucas crianças contem muitas histórias, enquanto a maioria só escuta. Assim, no conjunto de "sessôes" dessa brincadeira a que assisti, participaram, ao todo, 42 crianças, mas dentre elas somente 19 narraram uma história $(11$ meninas e 8 meninos, de 6 a 11 anos). E, dessas 19, somente 6 crianças ( 4 meninas e 2 meninos, de 8 a 10 anos) narraram mais da metade das histórias. Os narradores mais frequentes eram crianças de 8 e 9 anos: elas narraram três quartos das histórias recolhidas. $\mathrm{O}$ acesso à posição de narrador é, portanto, bastante desigual.

Ainda que os grupos sejam formados cada vez por cerca de cinco ou seis crianças, não é raro que apenas duas ou até mesmo uma só criança seja a narradora do começo ao fim da brincadeira. Os outros fazem breves comentários ("um caçador...", "mas olha já", "que medo") ou escutam em silêncio. Os menores vão e vêm. Ninguém reclamava de interrupçóes eventuais ou interferências sonoras. Eu não vi se formarem grupos só de crianças pequenas, onde talvez sem a presença dos contadores mais hábeis as menores se sentissem à vontade para experimentar o papel de narrador.

Uma vez dentro da brincadeira, as crianças não buscam a atenção dos adultos, nem tampouco se preocupam em ficar especialmente afastadas deles. Os adultos por sua vez não demonstram interesse pela atividade narrativa das crianças. Quando eu estava entre elas, às vezes as ouviam, fazendo cara de gozação. Como em outras situaçôes de aprendizagem, não corrigiam os aprendizes narradores e se contentavam em sorrir, dando a entender que não levam as crianças muito a sério. 
Entre as crianças, também não é comum uma corrigir a outra. Diante de uma hesitação, um gaguejar, ou de uma descrição pouco habitual de um personagem costumam interromper o narrador, "e o quê, Janaína!", "tá errado. Não sei o quê, mas tá

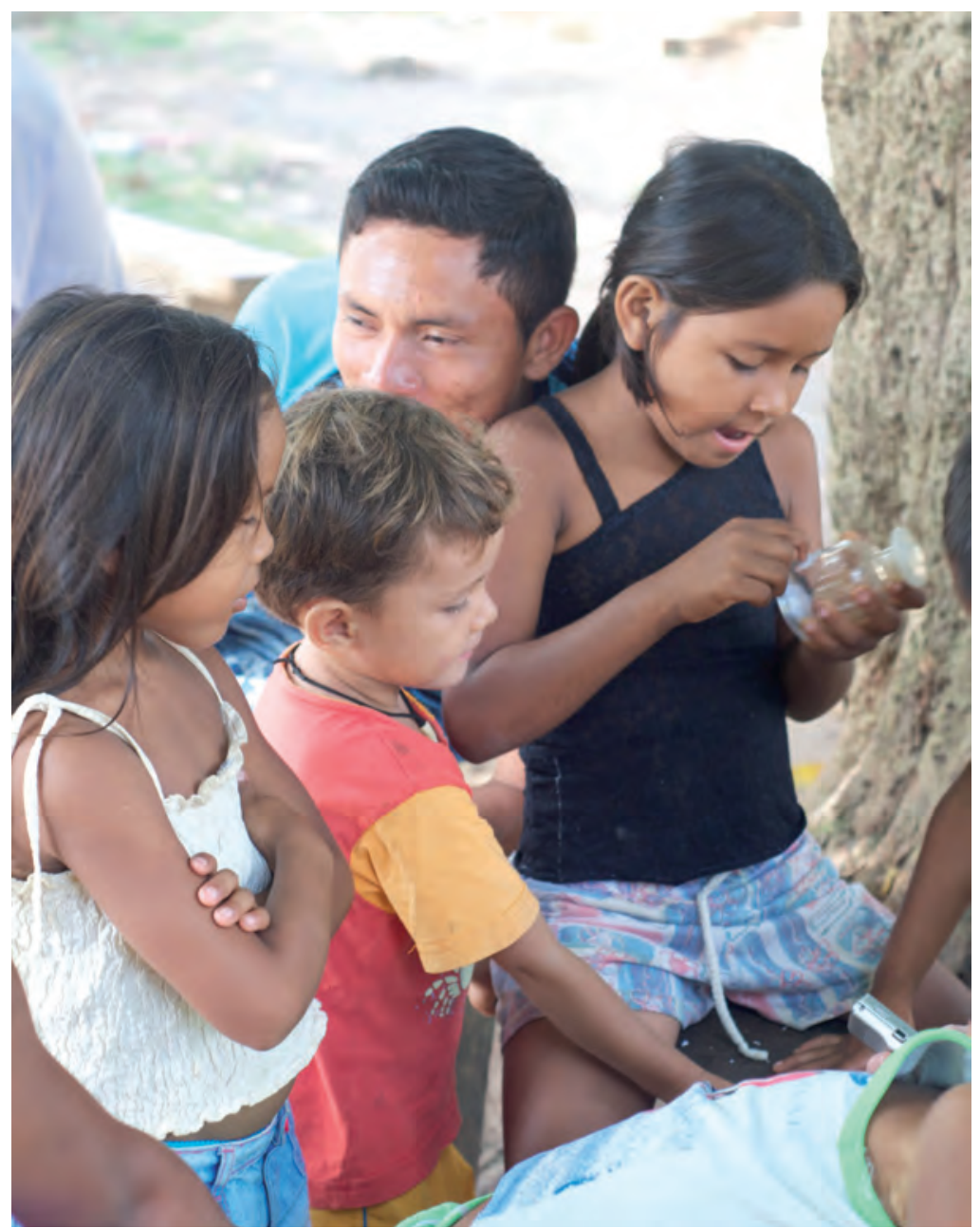

Janilton escuta alguns instantes e ri da história de Samara

(Pinhel, agosto de 2011).

Fotografia de Lucie Robieux. 
errado". Se o narrador se sente suficientemente confiante, pode tentar continuar a narrar e o comentário serve entâo de guia para melhorar sua performance. Mais comum é que aquele que havia interrompido tome a palavra, como se vê na interação abaixo, entre Wendel (5 anos) e seu irmão Wilson (7 anos):

Wendel: Era... um monte de homem. Foram caçar. De lá eles iam, iam, iam... [silêncio de alguns segundos]. De lá o medroso tava, tava lá em cima da árvore. De, de lá, de lá ainda eles iam, iam, iam...

Wilson: E o quê, Wendel! Tu nem sabe. Sou eu, eu vou contar. Vou contar uma bem feia. Era, eram três caçadores [...]

Nem todas as crianças se permitem interromper as outras. Nos momentos que observei, as que o faziam tinham um nível de competência similar ou, mais frequentemente, superior àquelas que interrompiam. Wilson, por exemplo, pôde produzir uma narrativa mais completa que aquela de Wendel:

Wilson: Eram três caçadores. De lá, quando eles chegaram numa barraca, tinha um monte de comida, aí um [caçador] comeu. Aí, quando ele ia caçar, escutou assim: "Auuuu." Era o bicho. De lá ele correu, o bicho: "Auuu." De lá, um [caçador] tava lá em cima da árvore. De lá o bicho veio de novo: "Auuu." O medroso tava lá em cima e caiu na boca do bicho. [...]

Comparando as duas versôes, vemos que na de Wendel o "medroso" já aparecia em cima da árvore antes mesmo que os caçadores tivessem encontrado uma barraca repleta de comida, e que o bicho se aproximasse. Quando essa mesma narrativa (que veremos ser uma das versôes da história do Jurupari) é feita por uma criança de 8 ou 9 anos, muitos são os detalhes que o narrador fornece sobre o espaço, a aparência física e as emoçóes dos personagens. 
As histórias "de bicho" dos adultos, em sua maioria, podem ser consideradas testemunhos, diretos ou indiretos, já que o personagem humano costuma ser um conhecido (fulano que mora em tal lugar, o tio tal, o pai, ou então o próprio narrador no caso de testemunhos diretos) e o enredo se passa num tempo e num lugar definido, lugar que o narrador e ouvintes conhecem (o porto da Pedra Branca, a ponta do Tapara, etc.). No entanto, o caráter verídico dos relatos é sempre duvidoso. $\mathrm{O}$ narrador pode reivindicar que se trata de "fato acontecido mesmo", dar detalhes que vêm corroborar sua declaração (outras pessoas que o testemunharam, marcas na paisagem deixadas pelo acontecido) ou pode ele mesmo confessar que o que conta "é só história", "são lendas", "histórias dos antigos"... Qualquer que seja o caso, os ouvintes são céticos sem ser descrentes: "A gente ouve sempre falar, né? Mas nem sempre a gente acredita. Só que tem muita coisa que contam que aconteceu mesmo, aqui, né? Então a gente fica sempre pensando...", explica Lidiana (43 anos). Mesmo que muitas histórias tratem de episódios de caça ou pesca, e que a maioria dos personagens humanos sejam homens, as narrativas são feitas tanto por homens quanto por mulheres.

Quanto às narrativas das crianças, a maior parte delas (72 das 86 histórias recolhidas) têm muitas características de um conto: os personagens são personagens-tipo, desprovidos de nome próprio ("eram três caçadores", "um pescador", "uma mulher"), o tempo é indefinido ("era uma vez", "foi um dia") e o local é mais vagamente delimitado que nas histórias dos adultos: não se trata, na maioria das vezes, da ponta $\mathrm{X}$, da trilha que vai até tal lugar, mas simplesmente da floresta, do rio ou da comunidade. Esses três ambientes são o cenário de todas as narrativas.

Há, no entanto, uma característica importante do que se define na literatura (escrita e oral) como conto, característica que alguns autores consideram como uma das "leis de gênero" 
(Belmont, 2001, p. 178), e que não se verifica nas narrativas de crianças do Tapajós: o final feliz. O protagonista humano termina morto em metade das histórias que recolhi; nas outras, ou ele simplesmente escapa (por pouco) com vida da agressão, ou ele escapa e também organiza uma expedição para se vingar e matar o agressor, em geral com requintes de crueldade. Para Nicole Belmont (2001, p. 181), pesquisadora de contos de tradiçấo oral, os finais infelizes em contos têm a ver ou com um lapsus ou com a inexperiência do narrador, já que os "contos são construçôes coletivas reacionais, que se destinam a lutar contra uma concepção trágica do destino humano". Os trabalhos clássicos do psicanalista Bruno Bettelheim (2010, p. 180-185) sobre os contos, assim como outras leituras psicanalíticas (por exemplo, Bellemin-Noël, 1983), também insistem sobre a função de reconforto e de apoio moral do final feliz, ao mesmo tempo sublinhando a importância da presença da violência e da brutalidade no desenrolar da trama do conto. Já outros autores, como o antropólogo François Flahault (2001), se opóem a essa visão, defendendo que muitos contos podem ser violentos $e$ terminar mal. Para Flahault (2001, p. 42), mais do que expressão de uma resoluçáo psíquica universal, os contos seriam uma forma de "expressão socializada de afetos, desejos e conflitos que nos atravessam todos"; seriam, assim, um dispositivo que expóe as crianças a maneiras culturalmente definidas de lidar com esses sentimentos universais.

No campo da antropologia das emoçóes, autores como Catherine Lutz (1988) e Michelle Rosaldo (1984) vêm mostrando, desde os anos 1980, o quanto as emoçóes humanas, seus significados e as formas de expressá-las são "estruturados por sistemas culturais e condiçōes materiais particulares" (Lutz, 1988, p. 5). É evidente que as narrativas destinadas às crianças, ou às quais elas são expostas com uma certa frequência, são um locus importante desse processo de construção social das emoçóes. Arthur Applebee (1978, p. 52), em seu clássico The child's concept of story, afirma que ouvir e contar histórias permite às crianças ampliar sua experiência do mundo e, ao mesmo tempo, desenvolver "expectativas relativamente estáveis 
sobre papéis e relaçóes próprias à sua cultura”. Nesse sentido, é interessante notar que no repertório de histórias orais que circula no Tapajós, reapropriado e transformado pelas crianças na brincadeira "da história", as narrativas nunca falam de eventos românticos (casamento, a busca ou o encontro de um amor) ou de situaçóes familiares (interação entre marido e mulher, entre pais e crianças, relatos de filhos abandonados, etc.). Praticamente todas as intrigas têm como tema central o encontro entre o protagonista humano e uma criatura não humana perigosa, que tenta devorá-lo ou sequestrá-lo. No contexto da escuta e narração de histórias, as crianças no Tapajós são, portanto, regularmente confrontadas com esse tipo de emoção e não com aquelas veiculadas em histórias românticas ou de conflitos intrafamiliares.

Examinemos a seguir então, mais em detalhe, o conteúdo dessas narrativas e os traços associados aos seus diferentes personagens.

\section{CONTEÚdo DAS HISTÓRIAS E CARACTERIZAÇÃo DOS PERSONAGENS}

\section{O QUE SIGNIFICA SER UM BICHO?}

Vimos até aqui que os bichos são os personagens mais frequentes das histórias narradas pelas crianças no Tapajós. ${ }^{6} \mathrm{~A}$ palavra "bicho" é, como se sabe, fortemente polissêmica (no dicionário há mais de 20 acepçóes); vejamos então o significado mais preciso que o termo ganha no contexto das histórias “de bicho” do Tapajós.

Em maio de 2011, Plínio (5 anos), Andressa (6 anos) e eu andávamos perto do rio quando Plínio, apontando um filhote de galinha-d'água, disse: "Outro dia, a gente conseguiu pegar um desses bichinhos." Andressa reagiu de pronto: "Isso não é

\footnotetext{
6 Das 86 histórias recolhidas, 75 falam de bichos. As outras são reinterpretações de contos tradicionais europeus que as crianças ouvem na escola.
} 
um bicho, isso é um animal!" Perguntei então qual diferença eles viam entre um bicho e um animal. "Bicho come gente", respondeu a menina, sem titubear.

Vejamos a seguir uma história na qual essa mesma ideia aparece de outra maneira. Tamires (9 anos) conta o encontro de dois caçadores com um bicho, que saberemos ao final da narraçáo ser o Jurupari.

[...] aí "tchá", atacou no meio dele, começou a comer na barriga. Eram duas carreiras de dente, em cima e embaixo, aí "crá, crá, crá", arrancava assim os pedaços. Os ossos ele [o bicho] jogou, assim. Aí ele foi embora, depois, "uuuu", gritando bem alto. Aí ele desceu, o outro [caçador], apavorado. Ele olhou assim, virou assim, viu já só a cabeça, já só, do outro [do caçador que foi atacado pelo bicho]. A cabeça tava lá, só a cabeça que ele não comia. Aí ele [a cabeça] falou assim: "Me leva, me leva", a cabeça. Aí, a cabeça já tava encantada. "Me leva, me leva contigo, me leva contigo, não me deixa morrer aqui sozinho, não!” Aí ele ficou com medo, né? Aí, tá. Ele jogou a cabeça assim lá com as coisas dele, pegou o rifle dele, colocou nas costas, né? E foi embora, descer o morro. [...] Aí andou, andou, andou... Aí uma hora começou a arder as costas dele. Quando ele jogou assim o jamaxim aquilo pegava nas costas dele, e era tudo sujo de sangue. A cabeça já tava comendo ele, já! Aí ele: "Compadre, tu já não é gente, não, tu já é um bicho!" Aí ele deixou [a cabeça] lá, correu, correu, pegou numa canoa e foi embora lá pra comunidade [...] Essa foi a história de um Jurupari.

A história continua com a organização de uma expedição coletiva para matar o Jurupari e náo girará mais em torno desse homem-cabeça, esse estranho sobrevivente do ataque do bicho. No entanto, é nessa figura que vou me concentrar em um primeiro momento. $\mathrm{O}$ fato de ter sido devorado e reduzido a uma cabeça falante náo foi suficiente para que o primeiro caçador considerasse que seu amigo tivesse sido transformado em uma criatura não humana. A narra- 
dora antecipa: "A cabeça já estava encantada", mas não diz o que pensa o caçador que não foi atacado. De toda maneira, com medo, o sobrevivente decide obedecer aos pedidos da cabeça falante e leva-a consigo, no jamaxim que carrega nas costas. Depois de um certo tempo de caminhada, vem o ato que o permite ter certeza de que seu (ex-)compadre havia perdido sua humanidade: o homem-cabeça tenta comer seu antigo companheiro de caçada pelas costas. Apenas a partir daí é que sua humanidade é vista pelo caçador que o transportava como definitivamente perdida: "Compadre, tu já não é gente, não, tu já é um bicho." Ele se tornou bicho, ou seja, uma criatura capaz de comer humanos. O caçador não agredido abandonará então a cabeça-bicho no meio da floresta, e seguirá sozinho seu caminho até a comunidade.

Vemos entâo que um simples animal não pode ser considerado um bicho, o que parece caracterizar o bicho é o fato dele ser um predador de humanos. Por isso onças, cobras e jacarés podem ser designados "bichos". "Bicho come gente", como disse Andressa. Mas não se deve esquecer o duplo sentido do verbo "comer" (ingerir e ter relaçôes sexuais), e veremos que alguns bichos tentam "comer" humanos mais no segundo sentido que no primeiro. Ou em ambos.

\section{O JURUPARI}

O Jurupari da história contada por Tamires é o bicho mais citado pelas crianças do Tapajós. ${ }^{7}$ Herói mítico em diversos grupos indígenas na época da colonização e ainda hoje, ${ }^{8}$ o Jurupari foi escolhido pelos jesuítas no século XVII para personificar o diabo (Daniel, 2004; Karadimas, 2007). Nos relatos de crianças

\footnotetext{
7 Dentre as 75 histórias "de bicho", 38 falam do Jurupari. A Curupira aparece em 16 narrativas e o Boto, em 9.

${ }^{8}$ Nos grupos em que existe um ritual associado ao Jurupari, a cerimônia está relacionada com a iniciação masculina e o Jurupari aparece ali materializado por flautas (que não podem ser vistas pelas mulheres). Sobre esses rituais ver, por exemplo, Karadimas (2007, 2008) e Reichel-Dolmatoff (1996). Aqui me concentrarei sobre as representaçóes atuais do Jurupari fornecidas pelos relatos dos meus interlocutores.
} 
e de adultos nas comunidades do Tapajós, o Jurupari não aparece nem como diabo, nem como herói. Ele é descrito como "homem bem grandão", com uma boca no rosto e outra no torso. Dessa boca ventral, ele também tira flechas para atacar quem o persegue. O Jurupari usa uma "capa" feita de "um bocado de coisa suja que ele ajeita assim. É besouro, é aranha, tudo sujeirada, coisa velha que ele arruma assim, na capa" (Geslaine, 7 anos) e é considerado "um índio velho" que não morreu, mas se transformou (se engerou) em Jurupari. Voltarei mais adiante a falar do verbo "engerar-se", um neologismo local.

A intriga das narrativas de Jurupari tem um núcleo relativamente estável, em torno do qual cada um insere variaçôes. A história começa com alguns caçadores (em geral três) que, andando na floresta, encontram uma casa ou abrigo de palha repleto de diversas variedades de carne de caça: "Desceram e desceram, até que chegaram, era uma casa assim de palha, bonito, aí lá tinha caça de, tinha caça de tudo lá. Tinha de paca, onça, cotia, anta, veado, tinha tudo lá" (Tamires, 9 anos). Algumas vezes, os caçadores encontram frutas, outras vezes, carne humana: "Tinha até carne de gente, tinha tudo lá" (Fernanda, 9 anos). Um dos caçadores se sente tentado a comer alguma das iguarias e outro tenta dissuadi-lo: "Rapaz, tu deixa aí. Tu não sabe de quem é isso aqui" (Bruno, 8 anos). Mas ele acaba fazendo um fogo, assando um pedaço de carne e comendo até se saciar. Seu(s) parceiro(s) apenas observa $(\mathrm{m})$. Em seguida os caçadores buscam uma árvore para subir e ficar "espiando caça", ou então apenas um deles, o medroso, sobe na árvore. Pouco depois, o Jurupari aparece. Ele reconhece quem comeu sua carne e o ataca. As crianças contam com muita intensidade, que se percebe em seu tom de voz e expressóes de medo e prazer combinados, o momento em que um dos caçadores é devorado, "chega escorria assim o sangue da boca dele" (Éric, 9 anos), "ele se lambia assim, comia os pedaços tudinho" (Camilly, 8 anos). E ressaltam que o Jurupari não come a cabeça de suas vítimas: "Ele comia só mesmo o corpo, deixava a cabeça, assim" (Bruno, 8 anos). 
Depois do ataque, se há sobreviventes, eles voltam para a comunidade e muitas vezes convocam outros homens para montar uma expediçâo para se vingar e matar o Jurupari. Um "índio" pode entáo aparecer como um personagem que sabe onde se esconde o Jurupari: "De lá, tinha um índio, um índio, aí ele: 'Eu sei onde é a casa desse tal de Jurupari'” (Bruno), ou então como alguém que mora com ele: "Aí, na caverna dele [do Jurupari] tinha um índio. Tinha muito índio, muito índio, era o reino dele lá com os índios, né?” (Éric). O relato pode ter um fim trágico para o Jurupari, os homens conseguem matá-lo com tiros ou, munidos de gasolina, ateando fogo em seu corpo. Ou entâo para os homens, que acabam devorados ou mortos por flechas atiradas pelo Jurupari, ou ainda se decidem nunca mais sair para caçar para evitar encontrá-lo. ${ }^{9}$ Se o Jurupari não come a cabeça de suas vítimas, nas narraçôes das crianças, sua cabeça é muitas vezes levada como troféu para a comunidade e fica ali exposta, até que os urubus se encarreguem de comer todos os restos: ${ }^{10}$

Aí levaram, trouxeram, aí colocaram, aí enfincaram a cabeça dele assim numa coisa, numa vara bem grandona, no meio da comunidade. Aí os urubus iam, né? Comiam tudinho, e só ficou mesmo a caveira. Aí a caveira foi, foi, foi, até que coisou, apodreceu, caiu. Aí acabou. Essa foi a história do Jurupari. (Éric, 9 anos)

Nas narrativas de crianças e de adultos que recolhi, o Jurupari não procura nunca interagir com os caçadores de

9 Das 38 narrativas sobre o Jurupari, em 17 ele morre e em 14 relatos são os homens que morrem (atingidos pelas flechas ou devorados). Duas histórias terminam com o fracasso da expedição e o caçador que "nunca mais foi caçar". Outras histórias têm um fim enigmático, "aí abriu, aí tava tudo eles morto no salão", "aí morreu tudinho, acabou a história”. Ou seja, há mortos, mas não sabemos quem.

${ }^{10}$ Vale notar que os Munduruku, povo indígena que vive no Alto Tapajós e com o qual moradores de comunidades na margem direta do Baixo Tapajós se identificam, eram guerreiros que mumificavam cabeças dos inimigos, considerando-as como troféus (Menget, 1985; Murphy, 1960). 
outra maneira que tentando devorá-los. Nada é dito também sobre o que ele faria fora do contexto de interação com o(s) caçador(es). Ele é um canibal feroz, o protótipo do "bicho do mato", selvagem e antissocial: "É uma coisa do mato, mesmo." Alguns adultos consideram que ele seja o próprio "mato" transformado em Jurupari: "Ele é o mato mesmo que se engera."

“ÍnDIO" сомо “вICHO”

Os preconceitos sobre os índios "selvagens" e perigosos, que "comem cru", "andam nus" e "fazem sexo como animais" são, ainda hoje, muito presentes na região. É, aliás, sem dúvida num esforço de se distanciar dessa imagem pejorativa que os moradores que reclamam uma identidade indígena preferem não ser chamados "índios" (termo que continuam, no entanto, a usar para designar povos indígenas de outras regióes), mas de "indígenas". Este termo, que conheceram no contato com pesquisadores, técnicos de órgáos governamentais e militantes do movimento indígena ganhou uma conotação mais positiva, de um indígena moderno e politizado (Boyer, 2015; Vaz, 2010).

A associação do Jurupari com os "índios" é direta: ele é considerado um "índio velho que se engerou num Jurupari”. Nas narrativas ele usa flechas, índios podem morar com ele (“é o reino deles ali”) ou saber onde encontrá-lo. Abaixo vemos uma outra história, narrada por Henrique (10 anos), onde o devir bicho de um "índio" aparece.

Uma vez um índio falou assim pra uma mulher: "Ei, vem cá que eu vou te falar um negócio." "O que é?" Ele falou: "Entra aqui." Não era pra ela entrar, se ela entrasse, ele ia comer ela. Aí ele falou: "Entra aqui no quarto." Aí de lá ele trancou ela, aí os dois ficaram lá no quarto e de lá ele falou assim: "Agora eu vou te comer. Eu tava se fingindo, agora eu vou te comer, agora." Ela: "Mamãe..." Mas tinha, no quarto tinha um pedaço de pau. Quando ele foi pra comer ela, ela pegou rápido o pau, de lá ela 
furou o olho dele. De lá ela saiu, quando chegou na porta, tinha uma bisa, uma bisavó. Ela olhou assim, de lá ela correu, né? Deu empurrão na bisavó, a bisavó correu, ela pulou mesmo por cima, ela caiu num buracáo, a bisavó. E de lá vinha um homem, um homem que nâo era bicho, né? [...]

O "índio" da história era, na realidade, um bicho e tenta "comer" a mulher. Não sabemos se a ameaça é de devorá-la literalmente ou sexualmente. A história continua, de maneira às vezes mais, às vezes menos compreensível, com uma intriga que toma emprestados elementos do conto Branca de Neve. A mulher e o "homem que não era bicho" (que aparece no final do trecho que transcrevi acima) acham um castelo e uma bruxa que oferece maçãs, cenouras e uvas envenenadas. Apesar dos alertas do homem, a mulher acaba comendo uma cenoura. Ela desmaia, mas acorda sozinha na manhã do dia seguinte - sem, portanto, a atuação de um príncipe, como no conto. A história acaba com seu despertar.

$\mathrm{Na}$ reapropriaçáo que fazem de contos tradicionais que escutam ou leem na escola, é comum que as crianças insiram personagens do repertório local. Na versão d'A velha gulosa contada por Bruno (8 anos), a velha é justamente uma "índia velha" que captura um menino que andava na floresta...

\section{Curupira, Macacão, Taú-Taú, Bicicleteiro}

A floresta é a morada de um sem-número de bichos. O segundo personagem mais citado pelas crianças, a Curupira, não somente mora ali, ela é, como vimos no capítulo anterior, considerada a "mãe da mata" e de tudo que vive nela. Algumas vezes ela aparece inclusive "na pele" ou "na capa" de alguma caça ("parece uma cotia, mas náo é", me explica Pedro, 43 anos).

Seo Juruparié sério, feroz, um tanto carrancudo, a Curupira tem alguma coisa de engraçada, safada e ao mesmo tempo ingênua. Ela se diverte ao fazer caçadores se perderem na floresta ou a surpreendê- 
los com um tapa que eles não sabem de onde veio. Nenhum dos dois (Curupira ou Jurupari) tem, no entanto, a sagacidade e a malícia que veremos ser exclusiva dos encantados "do fundo". A Curupira, por exemplo, se deixa enganar facilmente: "Quer ver ela ficar besta? É você pegar um pacote de tabaco, um copo de cachaça e um espelho. Deixa lá. É fácil de pegar ela. Ela quer se olhar pra ver se ela é bonita" (Pedro, diante da filha Gersiane, 8 anos). Teoricamente, esses presentes também podem lhe ser dados em troca do envio de animais para uma caçada abundante. Já vimos, no entanto (capítulo 5), que ela não é considerada muito confiável.

Jocilene (11 anos) e Camilly (8 anos) narram duas versóes de encontros com a Curupira. Enquanto a primeira segue uma trama muito comum, onde a Curupira engana o caçador fazendo com que ele se perca na mata, a segunda, numa narração de tom mais moralista, sublinha sua função de guardiã da floresta. Camilly termina inclusive com um comentário explicativo do tipo "moral da história" que poucas vezes ouvi, entre crianças ou adultos na regiáo.

O papai já ouviu uma já... Um dia, o papai Maró contou que a Curupira levou um homem, um homem que ia no caminho. Aí ele ia, ele ia no caminho, o homem. Aí uma Curupira chamou ele feito passarinho. Aí o homem queria, queria balar ela [acertar uma pedra jogada com estilingue], o passarinho, aí a Curupira se fingiu de passarinho, aí ela ia assobiando, e ia levando, ia fazendo o caminho. O homem ia atrás, ela ia levando. Encontraram ele muuuito longe já... (Jocilene)

Camilly fala de um caçador que "matou uma cotia, um veado, e mais um monte de cotia, né?" e acaba recebendo a visita noturna da Curupira: "Aí depois ele só viu aquele negócio, aquele vulto passando por perto dele, balançou a rede dele, aí fez bem assim: 'Fiiiiiii.' Aí ele se arrepiou tudinho..." A história continua com o caçador que segue a Curupira até sua casa, no tronco de uma árvore, e faz um trato com ela, que 
dessa vez será cumprido: o caçador trará "um litro de cachaça com cigarro e ainda mais um vinho" e a Curupira o deixará em paz. Camilly entấo conclui:

Ela... sabe por que ela aperreou ele? Porque quando, quando... na primeira caçada dele, que ele foi caçar, ele deu, ele atirou, ele matou muita caça, né? Ele abusou das cotiazinhas, já... Aí depois, aí depois quando ele foi deitar de novo na casa de forno, a Curupira, a Curupira, aí que a Curupira foi aperrear ele, que ela é dona da floresta, né? Ela náo deixa ninguém matar os animais, por isso que ela aperreou ele. Acabou a história.

Nas histórias das crianças, os homens que saem para caçar podem também encontrar um lobo, uma onça encantada (a Tapirauara) ou um bicho que tem todas as características do Jurupari, o Taú-Taú. Ele vive na floresta, algumas crianças dizem que ele dorme em uma caverna. Como o Jurupari, o Taú-Taú aparece para se vingar dos caçadores que tenham comido suas reservas de caça, mas, ao se aproximar, emite um grito típico: “Taú, taú, taú..." Os Taú-Taús se armam de arcos e flechas, que são às vezes queimados pelos moradores que os enfrentam: "De lá eles pegaram, quebraram tudinho os arcos dos bichos, fizeram um monte assim, de lá pegaram a gasolina, entornaram tudinho, aí "vuu", tocaram fogo. De lá eles morreram" (Éric, 9 anos).

Outros bichos preferem atacar as mulheres quando estas saem para trabalhar na roça. É o caso do Macacão invisível, que vive em uma caverna encantada. Ele rapta mulheres, que continuam a viver, encantadas, dentro da sua caverna. Esse personagem aparece em três relatos. Um deles acaba sem que o Macacáo seja morto e nos dois outros são as mulheres que conseguem matar seu agressor. Estéfany (9 anos) conta esta versão, com uma pequena participaçáo de Pirulito (8 anos):

Estéfany: Era do Macaco, o Macaco que pegou um monte de gente. Foi uma mulher lá pra, pro roçado dela. Aí, aí ele, o 


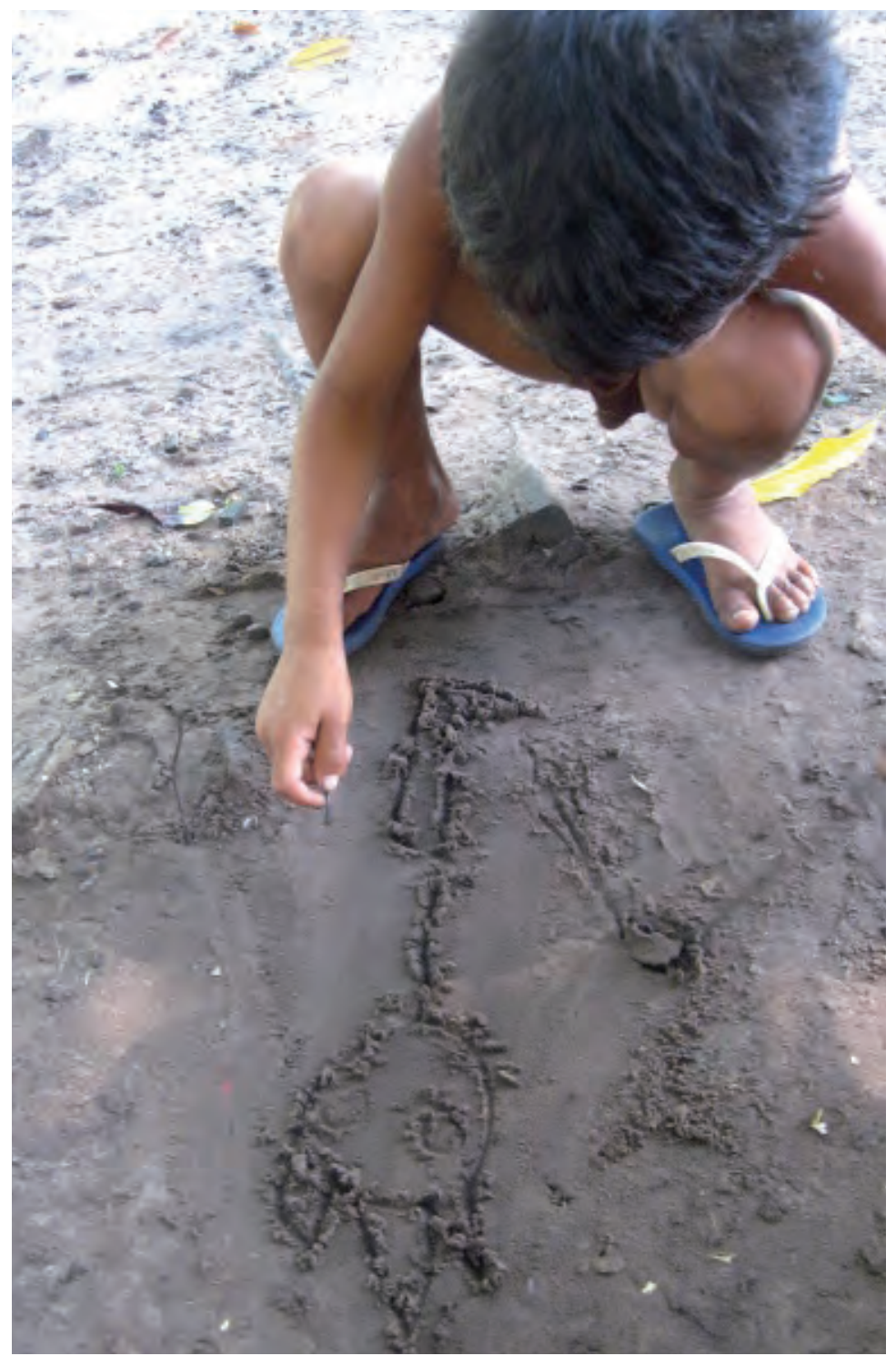

Menino de 5 anos desenha a Curupira na areia (Pinhel, novembro de 2010). Fotografias da autora. 
Macacão, ele era invisível. Aí ele pegou ela e levou pra lá pro... pro, como é?

Pirulito: Pro mato.

Estéfany: Não. Pra caverna. Pra uma caverna encantada. Aí ela se encantou pra lá e... Aí uma mulher, duas, três mulheres... três mulheres foram pra lá. Aí roçaram. Aí começou. Aí uma foi lá pro igarapé. Aí, aí o Macacão pegou ela lá. Ela falou: "Eu vou ficar lá na barraca.” Aí ele pegou lá, ficou uma lá. Aí ela gritou, gritou, gritou, gritooooou. Aí a amiga dela, ela foi embora lá pra casa dela. Ela chamou o, chamou uns homens lá. Aí era escuro pra lá. Aí ficaram escondidos lá. Aí, eles encontraram a caverna encantada. Os Macacóes coisaram, viram eles, aí era um monte de Macacão. Aí eles correram, correram. Aí tacaram flecha. Aí, [em] quem que pegava, aí morria. Aí... só que o Macacão ajudava também. Ele comia, aí... comia, comia, comia. Aí só ficou um. Aí foi embora lá pra caverna. Aí só ficou um, aí foi embora lá pra caverna. Aí, aí, aí o outro... aí virou Macacão. Aí ele virou Macacão. Aí ele foi já se acostumando pra lá. Aí tacaram fogo lá, só que o Macacão tava vivo num lugar aí. Pegou um monte de mulher de novo. Aí quando foi num dia, essas mulheres mesmo que mataram ele. Aí quando foi uma pra lá, ela não se encantou. Aí ela matou aquelas... ela matou, ela matou aqueles Macacóes lá. Ela não tava encantada. Era... eu esqueci o nome dela.

Pirulito: Acabou?

Estéfany: Acabou.

Outros "bichos do mato" podem também vir assombrar os moradores dentro da área da comunidade: a Corujona, um pinto encantado, o Cachorráo, o Bil ("que anda se arrastando"), e as crianças falam ainda do Bicicleteiro, do Chupa-Chupa, de um Pezão e do Cabeça-de-Cuia (bichos que não aparecem nas histórias dos adultos). As narrativas dizem que eles aparecem, sempre durante a noite, "só pra assustar" ou "pra dar uma surra nos cachorros", ou ainda para tentar sequestrar as pessoas e levá-las para "o mato". Alguns desses bichos têm traços que lembram aqueles de personagens mais 
conhecidos, como o Jurupari. O Bicicleteiro, por exemplo, "o corpo dele é cheio de lata, todinho o corpo dele e o rosto dele é cheio de lata velha. A bicicleta dele é tudo esculhambada, ela é tudo rachada, tudo rachadinha, tudo velha, ela é tudo cheia de corrente velha que ele cola uma em cima da outra", o que não deixa de lembrar a "capa" do Jurupari, feita de "um monte de imundice", "sujeirada", insetos e coisas velhas que ele cola "uma do lado da outra". Já o Chupa-Chupa lembra o midiatizado Chupa-Cabra de Minas Gerais. ${ }^{11}$

É interessante notar que fora desses momentos em que os moradores deparam-se com esses "bichos do mato", a vida das entidades silvestres não parece interessar os narradores. Tanto nas histórias dos adultos como nas das crianças, nada é dito sobre o que esses bichos poderiam fazer entre si, longe da companhia de humanos. Esse não é o caso para os "bichos do fundo", cujas narrativas analiso em seguida.

\section{BotO, UM BICHO DE FESTA E SEDUÇÃO}

Se os "bichos do mato" são associados à selvageria e à antissociabilidade, os "bichos do fundo", também perigosos, têm uma vida social ativa ("eles fazem festa, o pessoal ouve a música deles", Anderson, 8 anos) e buscam interagir com os moradores das comunidades pela via da sedução mais que pelo ataque direto. Eles têm o poder de "pegar a forma" que quiserem e escolhem a aparência de pessoas que os comunitários acham atraentes.

Como na história associada ao nome de Parauá (capítulo 5), a maioria dos encantados tomam a forma de um homem, mas acontece também deles aparecerem sob traços femininos, para seduzir homens. As crianças adoram contar uma história de um pescador que tem relaçóes sexuais com uma mulher loira, que entendemos ser o Boto temporariamente transformado. Mais

\footnotetext{
${ }^{11}$ Programas de televisão sensacionalistas, como Programa do Ratinho ou Cidade Alerta, bastante assistidos nas comunidades, falavam em 2011 do "mistério do Chupa-Cabra", o "desconhecido que suga o sangue de cabras e do gado até sua morte".
} 
tarde, quando ele está prestes a matar um boto (animal), durante uma pescaria, este se apresenta como seu filho e pede a bênção ao pescador! Eis a história narrada por Vanessa (11 anos):

É uma história dum pescador, né? Aí, tá. Todo dia ele saía pra pescar. Aí quando foi, ele gostava muito de dormir numa praia, né? Aí quando foi um dia, ele dormiu na praia e... Aí, aí ia toda vez uma mulher ia lá com ele, né? Era uma mulher loira, ela era bem bonita, ela. Aí, toda vez que ele ia pescar, né, os botos não, não deixavam ele pescar. Perseguiam ele. Aí foi, quando foi nesse dia ele convidou o parceiro dele. Aí ele disse: "Agora nós vamos, nós vamos fazer umas flechas de braço de inajá [palmeira] e nós vamos matar, flechar esses botos. Porque eles náo deixam a gente pescar.” Aí, eles fizeram. Chegaram lá, armaram a vara, esticaram a malhadeira tudinho. Aí tá. Não demorou lá vinha, né?, os botos em cima da água. Quando... tinha um, né, que vinha bem perto da canoa. Aí ele [o pescador disse]: "Agora é já!" E, quando ele ia pra zagaiar [flechar], o botinho disse: "A bênção, papai!"

A história, repetida por muitas crianças e adultos, termina com gargalhadas do narrador e de quem o escuta. Quando os adultos contam essa história, eles dão muito mais detalhes sobre o jogo da sedução que as crianças. Além disso, algumas crianças falam de uma troca que não é sexual, mas alimentar: "Ele tava com muita fome. Aí uma mulher chegou, era uma mulher loira. Aí chegou lá, ela deu, deu uma melancia pra ele. Aí ele comeu” (Estéfany, 9 anos).

Algumas crianças também narram a história do nome de Parauá e o encantamento da família por um "bicho do fundo", mas costumam introduzir elementos diferentes dos relatos dos adultos. Todas concordam que a família "ficou encantada", que os seus membros moram atualmente no porto da Pedra Branca e que suas pegadas podem ser vistas sobre as pedras próximas. Contudo, algumas dizem que foi uma onça quem os encantou (e não o Boto ou a Cobra-Grande); outras contam de um padre 
que aparece agora no lugar para celebrar a missa para "o povo encantado dali”. Outras contam ainda que foi a lua que caiu, e que "dá benzinho de ver" sua marca redonda nas pedras.

Vemos assim a manipulação inventiva feita pelas crianças das narraçóes que ouvem dos adultos e de outras crianças. Mantendo certos elementos que permitem aos ouvintes reconhecer a história em questáo ou, como diz Flahault (2005, p. 42), elementos que permitem "ativar no espírito de seus destinatários as representaçóes compartilhadas", as crianças inovam, inventam. Contudo, as inovaçóes náo se fazem de qualquer jeito, mas seguem certas regras: a lua é um elemento novo, mas ela deixa sua marca sobre as pedras assim como os pés das pessoas encantadas tinham deixado; uma onça encanta a família, assim como a Cobra-Grande ou o Boto teria feito; o padre aparece para rezar a missa para os encantados, confirmando o interesse dos narradores da região sobre a vida social dessas entidades. Essas variaçóes regradas, que fazem parte das especificidades da literatura oral (Belmont, 1999; Bru, 1999), são aqui exacerbadas pelo processo de aprendizagem infantil. As crianças tentam, inventam e se confundem também. É a reação do público que dirá quais são os limites da inovação - e do erro. Ou os ouvintes aprovam a modificação (não interrompem e nem vão embora) e, eventualmente, repetem a versão mais tarde. Ou então eles desaprovam, tomam a palavra do narrador, ou deixam-no falando sozinho.

Nas diferentes versóes da história que teria dado o nome a Parauá, há um outro ponto que não varia entre adultos e crianças, é o fato do encantado sequestrador da família ser considerado como a máe, ou o dono daquele lugar.

\section{O OlHAR DOS DONOS OU MÁES}

Já vimos no capítulo precedente os contornos gerais da posição de donos e mães dos lugares ou dos animais de uma determinada espécie, e o que significa, para os moradores da região, 
respeitar essas entidades. Vejamos aqui somente um detalhe a mais que aparece de maneira especialmente vívida nas narrativas das crianças: o perigo do olhar desses bichos-donos.

Tamires ( 9 anos) conta a história da Tapirauara, uma onça encantada, metade onça, metade boi:

Ela é uma onça que ela gostava de querer ser boi, aí ela se encantou [...] e ela era, ela era que nem um boi, mas ela náo tinha o couro do boi. O couro dela era de onça mesmo, e a cara, o resto era de boi. Ela era grande que nem um boi mesmo formado, aquelas novilhas grandes, sabe? E o casco dela era de boi. [...] Ela vem atrás de quem mata muita onça, que ela é tipo a mãe delas, né?

Dois caçadores a encontram na floresta, após terem matado duas onças, que carregavam consigo. Um dos caçadores olhou diretamente para a Tapirauara, "ele olhou logo pra ela né? Ficou com medo", enquanto o outro "abaixou a cabeça e ficou com o olho fechado". O primeiro foi devorado ("ficou já só osso velho, a cabeça ainda tava com um pouquinho de carne"), o segundo, não. De volta à comunidade, os sobreviventes organizam, com a ajuda de um homem "que sabia bem a história dela", uma expedição para matar a Tapirauara. Eles conseguem fazê-lo porque o homem deixou claro: "Náo olhe pros olhos dela, que ela encanta." "Aí todo mundo abaixou assim a cabeça, pegou o rifle, começaram atirar, aí deram seis tiros nela, só no pescoço. [...] Aí ela foi pra querer subir [na árvore], mas ela não conseguia, né? Porque ela não tinha unha. Ela tinha casco, de boi." Os homens ouvem então ao longe o rugido de uma Tapirauara macho ("essa daqui era uma fêmea, ela tava procurando macho pra ela”), então fogem levando o couro da onça-boi para vender. 
Os adultos da região não cessam de lembrar do perigo da "olhada de bicho" e da "flechada de bicho". ${ }^{12}$ Quantas pessoas relatam ter começado a sentir fortes dores de cabeça, fraqueza ou entấo ter perdido um filho que o "bicho olhou". Quando uma doença desse tipo se instala, a única chance possível que se tem é buscar a ajuda de um curador, um pajé que pode, justamente com a ajuda dessas entidades, encontrar um tratamento para o doente.

Se continuamos explorando as histórias das crianças, há ainda um personagem que aparece ali e que não mencionei até o momento. Recomendações de conduta também serão associadas a ele, mas nesse caso não se trata de não "provocar" ou não "abusar" da sua paciência, e sim de evitar a sua própria transformação em um engerado.

\section{Os ENGERADOS}

Para os moradores do Tapajós, um engerado é uma pessoa (viva), um morador, que se transforma (se engera) durante a noite em um animal, em geral de maneira involuntária. Trata-se sempre de uma pessoa de idade que teria cometido um "pecado mortal" durante sua vida e que, na sua velhice, não pode escapar desse "fardo". O processo é visto assim como uma penitência. ${ }^{13}$ Os moradores da região consideram "pecado mortal" práticas incestuosas ("é irmão com irmão, o filho com a mãe"), de feitiçaria ("fazer coisa feita pra alguém", "coisa mandada") ou o fato de bater nos pais. Assim, dizer de alguém que ele se engera é uma acusação pesada, que circula sobretudo na forma de rumores.

\footnotetext{
${ }^{12}$ Maués (1990, p. 103 e ss.) descreve o poder maléfico da "olhada de bicho" no sistema de doenças e curas da "pajelança cabocla". Outras etnografias da região e do vale do Amazonas também o mencionam.

${ }^{13}$ Ver descrições similares em Mahalem de Lima (2015, p. 361 e ss.), Vaz (2010, p. 164 e ss.) e Stoll (2016). Elas diferem da interpretação de Wawzyniak (2003, 2012), que não distingue as transformaçóes por engeramento de outras formas de transformaçóes, como o encantamento.
} 
O uso do termo "engerado" parece próprio à regiáo do Baixo Tapajós e do Arapiuns, mas histórias similares de transformaçōes noturnas de humanos em animais, ligadas a uma condenaçâo moral expressa num idioma de origem católica, foram observadas em outras regiōes da Amazônia (Galvão 1955, p. 79; Harris, 2008, p. 45; Slater, 1994, p. 140-143), às vezes com a utilização do verbo "gerar" para indicar a transformação. O neologismo local "engerar-se" parece assim ser construído a partir do verbo "gerar", ao qual se adiciona o prefixo "en-" ${ }^{14} \mathrm{O}$ termo pode se declinar em adjetivo ou locução adjetiva (estar engerado; ser uma pessoa que se engera), em substantivo (um engerado), em verbo (engerar-se) ou entáo pode designar o processo de transformaçáo (uma engeraçáo ou um engeramento).

Para os habitantes do Tapajós, os homens se engeram em animais domésticos ou de criação (cavalo, porco, bode, galo), e as mulheres, mais comumente em um animal predador (onça, cobra, coruja), mas também em porcas. Se pajés e curadores podem resolver doenças "de bicho", eles nada podem fazer para interromper o processo de engeraçáo. Fernanda (9 anos) narra uma história de um caçador que conseguiu deixar de se engerar ao aprender a rezar. Os adultos da região não costumam considerar que esse processo seja tấo facilmente interrompido. Quem se engera, dizem, deverá carregar esse fardo até o fim da vida. E ainda, muitas vezes, só conseguem morrer quando alguém da família lhes recita preces específicas (de origem católica). Na narrativa de Fernanda, vemos um homem que se engera em um cavalo e serve de montaria ao diabo:

Eu vou contar uma. Era uma vez... dois homens foram [caçar], eram dois homens e tinha um que se engerava. Aí, aí: "Bora caçar?" "Vamos." Aí foram. "Bora tirar seringa?" "Vamos." Aí, aí na hora que chegaram lá na barraca um falou: "Ah, tô muito

\footnotetext{
${ }^{14}$ Que também poderia ser grafado “in” (“ingerado”, “ingerar-se”, cf. Vaz, 2010, p. 151,164). Optei pelo prefixo "en-” que é mais comumente utilizado para indicar uma passagem, uma transformaçáo de um estado a outro (entristecer, encarecer, etc.).
} 
mal." "Então fica aqui fazendo almoço que eu vou tirar seringa" [disse o outro]. Aí, aí ele foi tirar seringa. Aí, tá. Ele tava lá, aí ele [o que foi tirar seringa] voltou, aí ele [homem que ficou na barraca] tava láaa dormindo. Aí ele escutou "parará parará parará parará". Aí, aquele outro só tava escutando. Aí o diabo deu quatro, é, lapadas nele. Aí ele virou um cavalo. Aí, aí ele virou um cavalo e diabo montou em cima dele e foi embora. Aí, "parará parará parará". Aí de noite ele apareceu de novo, "parará parará parará". Aí, aí o amigo dele já tava escutando. Aí, aí ele, ele chegou lá na barraca. Aí ele chegou lá na barraca, aí ele deu quatro lapadas, aí ele caiu no chão e já era gente. Aí, aí ele se deitou na rede, aí ele foi se deitar na rede, aí o coisa, o outro, falou assim: "Amigo" "O quê?" "Bora rezar?" Aí ele ensinou ele a rezar. Aí o, aí ele rezou. Aí, tá. Aí: "Eu vou tirar seringa." Aí, só que aí ele tava mentindo. Aí ele foi, ele ficou escondido lá em cima duma árvore. Aí o diabo foi lá de novo, "parará parará parara”. Aí, aí, aí ele, aí quando o diabo chegou lá ele não conseguiu dar a lapada nele porque já tinha rezado, já. Aí terminou a história.

Ouve-se o diabo chegando, "parará parará parará” (barulho de seus cascos). Ele "dá quatro lapadas" no homem e este "vira um cavalo", que o diabo usa durante a noite e vem devolver de manhã. $\mathrm{O}$ fim da história é bastante moralizante. Quando seu amigo o ensina a rezar, o diabo tenta mas não consegue mais colocar o homem a seu serviço. Os adultos também costumam mencionar essa ideia do engerado como "servidor" do diabo.

É interessante notar a escolha de vocabulário operada para falar de diferentes transformaçóes. Já vimos que, em outras narrativas, processos transformativos são indicados pelo verbo "encantar-se": o homem-cabeça, sobrevivente do Jurupari, "estava encantado"; Tapirauara "se encantava" a cada três dias; a família "foi encantada" na entrada do Amorim; o Macacão invisível "encanta" as mulheres. $\mathrm{E}$ existem os seres considerados como encantados: as entidades "do fundo" (Boto, Cobra-Grande, etc.), o Macacão invisível, o Pretinho que mora embaixo da pedra em Pinhel, a Tapirauara e, 
para alguns, a Curupira. Quando algum desses encantados assume uma aparência humana ou de um animal, os moradores dizem que ele "se transforma", "pega a forma", que ele "se vira em", "aparece na capa de". Não se dirá em nenhuma circunstância que ele se engera. E nem mesmo se dirá que ele "se encanta"... Encantar-se parece assim indicar uma transformação num só sentido: em direção do encante; quem seencanta, é porque passa a ser um encantado, definitivamente. Esses mesmos seres encantados, quando se transformam temporária e voluntariamente em humanos, apenas "pegam a forma", "vêm com a capa" de um outro ser, mas não deixam de ser um encantado.

Já o verbo "engerar-se" tem seu uso restrito a um processo transformacional ligado a uma condenação moral: trata-se da transformação de um morador conhecido, condenado por seus "pecados mortais" a servir o diabo durante a noite. Além disso, os moradores da regiáo usam esse termo para falar, como vimos, do Jurupari, que seria, na verdade, um "índio velho engerado em Jurupari”. Tendo em vista os preconceitos que circulam sobre os índios na região, não é difícil imaginar que condenaçôes morais, expressas em um vocabulário de origem católica, lhe sejam atribuídas.

\section{CONCLUSÃO: APRENDER DAS NARRATIVAS}

Gostaria, por fim, de destacar um ponto que concerne especificamente ao processo de aprendizagem dessas histórias. Vimos que as crianças que narram as histórias são sobretudo aquelas de 8 e 9 anos. Os ouvintes dáo mais dificilmente atenção aos mais novos e os mais velhos começam a preferir intervir em outros grupos. Os menores também não buscam formar novos grupos entre si, onde poderiam experimentar o papel de narradores, longe do julgamento dos mais velhos. Essa configuração me parece ser reveladora das dinâmicas de aprendizagem na regiáo: observar e escutar os mais experientes, depois experimentar-se entre pares parece assim a estratégia 
privilegiada. No entanto, esse "entre pares" mostra-se na verdade um grupo bastante restrito de pessoas, constituído daqueles que já sabem o suficiente, sem sentir que já sabem o suficiente para intervir num grupo de mais experientes... E como as exigências são altas, a seleção operada para decidir o que é "suficiente" resulta na entrada de poucos indivíduos nesse grupo seleto, no interior do qual a diferença de competência é pequena e há sem dúvida uma liberdade de experimentação que não existe em outros lugares. Assim, a configuração dos grupos da brincadeira "da história" mostra bem o caráter seletivo da modalidade de aprendizagem local.

No que se refere às competências que as crianças desenvolvem nessa brincadeira, elas incluem tanto uma dimensão ligada à performance narrativa, um certo estilo de enunciaçáo (tom de voz, ritmo, capacidade de criar suspense, gestos, expressóes corporais, faciais), como também o conhecimento das diferentes características e papéis dos personagens das histórias. Aprendendo sobre as regras de interação entre os diferentes tipos de bichos e de humanos as crianças do Tapajós estáo, ao mesmo tempo, aprendendo importantes regras de conduta local. Saber o que deve fazer um caçador ou uma mulher que vai à roça para não "provocar" ou "abusar" de tal ou tal bicho é útil, de maneira imediata, para que sua trama narrativa se torne mais convincente, e, ao mesmo tempo, informa comportamentos sociais futuros, fora do plano narrativo. Tanto para a construção imediata da trama narrativa como para os comportamentos futuros, crianças e adultos manejam e compóem essas informaçôes de maneira criativa, dando sequência ao processo de continuidade transformadora do jogo social. 